\title{
A stem/loop in U6 RNA defines a conformational switch required for pre-mRNA splicing
}

\author{
David M. Fortner, Raymond G. Troy, and David A. Brow ${ }^{1}$ \\ Department of Biomolecular Chemistry, University of Wisconsin, Madison, Wisconsin 53706-1532 USA
}

\begin{abstract}
U6 small nuclear RNA (snRNA) is an essential component of the spliceosome, the ribonucleoprotein complex that carries out the splicing of pre-mRNAs. The precise function of U6 RNA is unknown, but it has been proposed to participate directly in catalysis of the splicing reaction. We present biochemical and genetic evidence for an intramolecular stem/loop structure in the 3' half of U6 RNA of the yeast Saccharomyces cerevisiae that is mutually exclusive with the intermolecular base-pairing between U6 RNA and U4 snRNA. Strains with mutations that stabilize the U6 RNA 3 '-intramolecular stem exhibit cold-sensitive growth and accumulate free U4 RNA, indicative of a block in U4/U6 snRNP assembly. The cold sensitivity can be partially suppressed by overexpression of U4 RNA. Mutations that disrupt base-pairing in the intramolecular $3^{\prime}$ ' stem and mutations elsewhere in U6 RNA also suppress the growth defect. We conclude that a large conformational switch, involving melting of the U6 RNA $3^{\prime}$ stem, is required for U4/U6 snRNP assembly. We hypothesize that formation of the U6 RNA intramolecular 3' stem after U4 RNA leaves the assembled spliceosome serves to activate U6 RNA for splicing by juxtaposing regions in U6 RNA that interact with U2 small nuclear RNA.
\end{abstract}

[Key Words: U6 RNA; splicing; yeast]

Received September 1, 1993, revised version accepted November 29, 1993.

U6 RNA is one of five RNAs that, along with at least 30 proteins, assemble on the pre-mRNA to form a large complex called the spliceosome, which is capable of precisely excising an intron and ligating the corresponding exons (for review, see Green 1991; Guthrie 1991; Rymond and Rosbash 1992). Because nuclear pre-mRNA splicing utilizes a two-step chemical mechanism identical to that of self-splicing group II introns (Peebles et al. 1986; van der Veen et al. 1986), it is likely to be an RNA-catalyzed reaction. Involvement of U6 RNA in the catalysis of splicing has been proposed (Guthrie and Patterson 1988; Brow and Guthrie 1989).

A 39-nucleotide sequence that is degenerate at only one position is found in the center of almost all sequenced U6 RNAs (Fig. 1A). In contrast, the sequences flanking this conserved core display considerable degeneracy. Only two variants of the conserved core sequence have been identified: one in a subset of yeast genera (including Saccharomyces; Fig. 1A) and one in trypanosomes (Tschudi et al. 1988; Mottram et al. 1989). Both have eight changes from the core sequence. Most of the point mutations tested in the conserved core of yeast U6 RNA partially or completely block splicing in vitro, whereas none of those tested outside of the conserved

\footnotetext{
${ }^{1}$ Corresponding author.
}

core have any effect (Fabrizio and Abelson 1990). Likewise, most of the point mutations tested in the conserved core are lethal or conditional lethal in yeast, whereas none of those tested outside of the conserved core alter the growth rate significantly (Madhani et al. 1990; Madhani and Guthrie 1992). Clearly, the conserved core of U6 RNA plays a vital role in pre-mRNA splicing.

Phylogenetic, genetic, and biochemical evidence indicate that two-thirds of the conserved core of U6 RNA base-pairs to U4 RNA in the U4/U6 snRNP (Bringmann et al. 1984; Hashimoto and Steitz 1984; Rinke et al. 1985; Brow and Guthrie 1988; Vankan et al. 1990; Shannon and Guthrie 1991; Fig. 1A). More recently, genetic studies have identified an essential base-pairing interaction between part of the conserved core and a region of U2 RNA close to the branchpoint-pairing region (Madhani and Guthrie 1992), and chemical cross-linking studies have revealed base-pairing between one end of the conserved core and the 5'-splice site of the pre-mRNA (Sawa and Abelson 1992; Sawa and Shimura 1992; Wassarman and Steitz 1992). U6 RNA enters the spliceosome complexed with U4 RNA, but before the catalytic steps of splicing occur, base-pairing between U4 and U6 RNAs is disrupted and U4 RNA may leave the spliceosome (Pikielny et al. 1986; Cheng and Abelson 1987; Konarska and Sharp 1987; Lamond et al. 1988; Yean and 
Lin 1991). Disruption of the U4/U6 interaction is thought to allow pairing of the conserved core with U2 RNA (Madhani and Guthrie 1992; see Fig. 1A).

The conserved core may also participate in intramolecular base-pairing when U6 RNA is not complexed to U4 RNA. Because U6 RNA is present in excess of U4 RNA, much of the cellular U6 RNA is found free of U4 RNA (Cheng and Abelson 1987; Siliciano et al. 1987). A secondary structure model of free U6 RNA, first postulated when the sequence of mammalian U6 RNA was determined (Epstein et al. 1980; Harada et al. 1980), includes a stem/loop structure in the conserved core, here called the $3^{\prime}$ stem (Fig. 1A). The yeast variant of the conserved core contains compensatory base substitutions at two positions in the $3^{\prime}$ stem, providing limited evidence in support of its existence. In summary, the conserved core of U6 RNA appears to adopt at least three different conformations: one in the U6 snRNP, another in the U4/U6 snRNP, and a third when base-paired to U2 RNA and pre-mRNA in the spliceosome.

Here, we present chemical modification data that strongly support the existence of the $3^{\prime}$ stem of yeast U6 RNA in vivo. Furthermore, we show that mutations expected to increase the stability of the 3 ' stem reduce the level of U4/U6 complex in cellular RNA and inhibit cell growth at low temperature, consistent with the proposal that a large conformational switch in the $3^{\prime}$ stem is required for U4/U6 snRNP assembly. Overexpression of U4 RNA in a strain containing a 3' stem hyperstabilization mutation results in wild-type levels of U4/U6 complex but only partially suppresses the low-temperature growth defect, suggesting that other effects of the mutation also contribute to cold sensitivity. Spontaneous suppressors of a 3' stem hyperstabilization mutation arise in the $3^{\prime}$ stem itself, in regions of U6 RNA broadly flanking the $3^{\prime}$ stem, and in other genes. Some suppressors do not correct the U4/U6 snRNP assembly defect, indicating that there is more than one mechanism of suppression. Possible effects of $3^{\prime}$ stem hyperstabilization mutations on the U2/U6/pre-mRNA complex are discussed.

\section{Results}

In vivo secondary structure of yeast U6 RNA

Figure 1B shows our current secondary structure model for Saccharomyces cerevisiae U6 RNA. Phylogenetic comparisons have previously established the existence of a variable-length 5'-terminal stem/loop in U6 RNA (nucleotides 1-25 in yeast; Brow and Guthrie 1988; Roiha et al. 1989). Evidence for the formation of two additional stems came from in vitro transcription of the S. cerevisiae U6 gene, SNR6, in a yeast subcellular extract (Eschenlauer et al. 1993). A 3'-nuclease activity present in the extract produces major breakdown products of the 112-nucleotide U6 RNA that are $\sim 90$ and 60 nucleotides in length. We surmised that the nuclease pause sites correspond to the $3^{\prime}$ borders of two intramolecular stems, which we call the central and $3^{\prime}$ stems (Fig. 1B). The yeast $3^{\prime}$ stem corresponds to the top por- tion of an extended stem/loop proposed for mammalian U6 RNA (Epstein et al. 1980; Harada et al. 1980) and is almost completely contained within the conserved core (Fig. 1A). In contrast, the central stem suffers multiple noncompensatory changes in other organisms and so would be considered phylogenetically disproven.

To determine whether the $3^{\prime}$ stem exists in vivo we employed chemical structure probing. Dimethylsulfate (DMS) diffuses into living cells and methylates $\mathrm{A}$ and $\mathrm{C}$ residues in single-stranded, but not double-stranded, RNA (Ares and Igel 1990). The modified bases can be detected in isolated RNA as termination points for reverse transcriptase (Inoue and Cech 1985; Moazed et al. 1986). Because only $\sim 20 \%$ of the U6 RNA in yeast is complexed with U4 RNA (Li and Brow 1993; see below), modification of the U4/U6 complex should only represent a minor fraction of the overall U6 RNA methylation pattern.

The results of reverse transcription of yeast U6 RNA modified in vivo with DMS are shown in Figure 1C and are summarized in Figure 1B. These data strongly support the existence of the 3 ' stem/loop in vivo. Two of the three loop residues (C72 and $\mathrm{A} 73$ ) that can be probed with DMS are modified to an extent similar to that of residues (A12-C15) in the loop of the $5^{\prime}$-stem/loop, the existence of which is confirmed by our analysis. Furthermore, $\mathrm{A}$ and $\mathrm{C}$ residues in the $3^{\prime}$ stem are strongly protected from modification, except at one A-C mismatch. This A-C mismatch is adjacent to a bulge $\mathrm{U}$ near the top of the $3^{\prime}$ stem and is only weakly modified. The other A-C mismatch, near the base of the stem, is protected from modification. A-C base-pairing occurs at acidic $\mathrm{pH}$ as a result of protonation of the adenosine base at position N1 (the site of DMS methylation). Recent evidence suggests that A-C pairs may also form at physiological $\mathrm{pH}$ (see Discussion).

The evidence for the central stem is less conclusive. Significant, but incomplete, protection is seen at all residues in the $3^{\prime}$ strand of the stem that are predicted to be base-paired. Incomplete protection in the central stem could be explained by "breathing" (transient disruption) of the stem during the 2-min incubation or may reflect absence of the stem in a subpopulation of the U6 RNA. There are just two $\mathrm{A}$ or $\mathrm{C}$ residues expected to be basepaired in the $5^{\prime}$ strand of the central stem, and only one is significantly protected. Therefore, we cannot rule out the possibility that residues in the $3^{\prime}$ strand are protected from methylation by some other interaction.

The in vivo DMS modification pattern of U6 RNA is also consistent with the proposed U2/U6/pre-mRNA interaction, which contains the $5^{\prime}$ - and $3^{\prime}$-intramolecular stems of U6 RNA and pairs the central-stem region with U2 RNA and pre-mRNA (see Fig. 5C, below). However, it seems unlikely that a large fraction of the cellular U6 RNA is in this complex. Furthermore, gel-purified yeast U6 RNA gives a similar pattern when modified with DMS in vitro (data not shown). We therefore interpret the in vivo DMS modification pattern as reflecting primarily the secondary structure of U6 RNA in the U6 snRNP. In any case, the modification pattern clearly sup- 
A

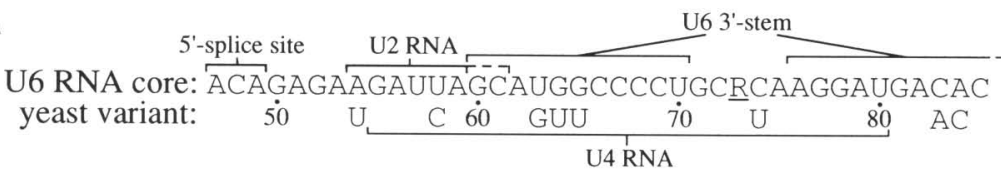

B

\section{S. cerevisiae U6 RNA}

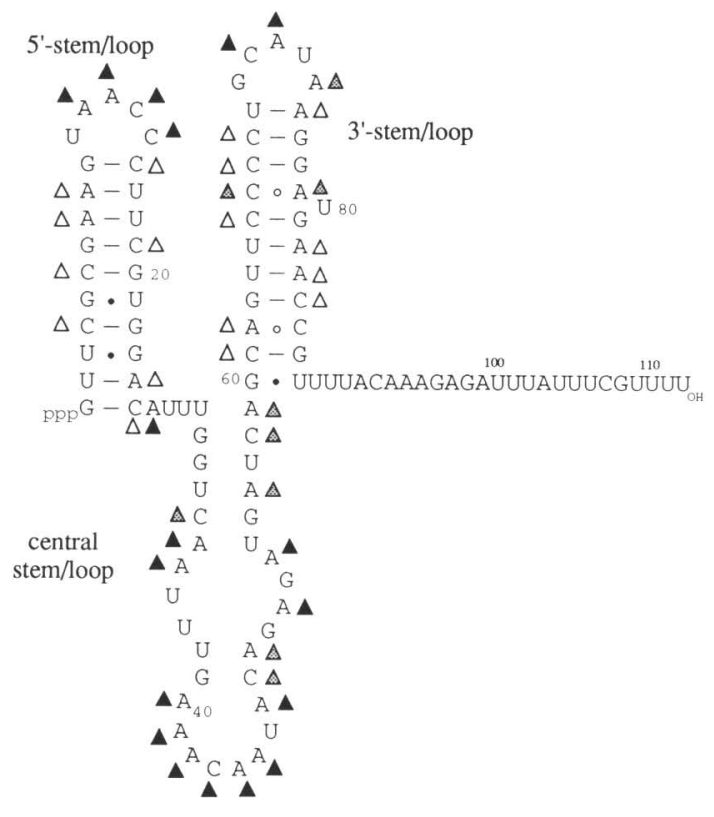

Figure 1. Secondary structure of U6 RNA. $(A)$ Conserved core of U6 RNA. The 39-nucleotide sequence found in U6 RNA from human, mouse, rat, Xenopus, Drosophila, Caenorhabditis, Tachypleus, bean, tomato, maize, wheat, Arabidopsis, Tetrahymena, and various yeast genera (Roiha et al. 1989; Shumyatsky and Reddy 1993) is labeled U6 RNA core. The underlined position can be either purine. The eight nucleotide changes found in the yeast genera Saccharomyces (Brow and Guthrie 1988), Kluyveromyces (Guthrie and Patterson 1988), and others (based on partial sequence; Roiha et al. 1989) are labeled yeast variant. Numbering is according to the $S$. cerevisiae sequence. Base-pairing interactions are indicated with brackets (for details, see Fig. 5). (B) Proposed secondary structure of $S$. cerevisiae U6 RNA with a summary of the in vivo DMS modification data (Fig. 1C; data not shown). (Open triangles) $\mathrm{A}$ and $\mathrm{C}$ residues unmodified by DMS; (shaded triangles) weakly modified; (solid triangles) strongly modified. Base pairs in the potential central stem/loop are not shown because they are not supported by phylogenetic analysis. $(C)$ Primer extension analysis of U6 RNA modified in vivo with DMS DMS + or mock-modified (DMS -). Methylation of $A$ and $C$ residues by DMS results in termination of reverse transcriptase 1 base prior to the modified base. $\mathrm{A}$ and $\mathrm{C}$ sequencing ladders are shown for reference. The shaded areas indicate portions of the indicated stem structures. ports the existence of the $3^{\prime}$ stem in the major fraction of cellular U6 RNA.

\section{Effects of hyperstabilization of the U6 RNA 3' stem}

Because the U6 RNA $3^{\prime}$ stem and the region of U6 RNA that base-pairs with U4 RNA overlap significantly (Fig. 1A), U6 RNA must undergo a major conformational change during U4/U6 snRNP assembly. Hyperstabilization of the $3^{\prime}$ stem would be expected to inhibit this conformational switch, thereby reducing the steadystate level of U4/U6 complex and, presumably, of active spliceosomes. A decreased growth temperature should exacerbate the assembly defect, as melting of the $3^{\prime}$ stem would be further inhibited, so hyperstabilization mutations may result in cold-sensitive growth. To test this prediction, we chose to hyperstabilize the $3^{\prime}$ stem by substituting positions 62 and 79 , as changing either $A$ to a $\mathrm{G}$ forms a stable G-C base-pair (Fig. 2A), while having minor effects on $\mathrm{U} 4 / \mathrm{U} 6$ pairing (both change an $\mathrm{A}-\mathrm{U}$ base-pair to a G-U).

Each altered version of the U6 gene, snr6-A62G and
snr6-A79G, was introduced on a TRP1-marked centromere plasmid into a strain (DAB016) containing a chromosomal U6 gene disruption and the wild-type U6 gene on a URA3-marked plasmid. Neither mutant allele had a dominant effect on growth at $18^{\circ} \mathrm{C}, 30^{\circ} \mathrm{C}$, or $37^{\circ} \mathrm{C}$. After selecting for loss of the URA3 plasmid by plating on medium containing 5-fluororotic acid (5-FOA), strains containing only the mutant U6 RNA were scored for growth at $18^{\circ} \mathrm{C}, 30^{\circ} \mathrm{C}$, and $37^{\circ} \mathrm{C}$. Each single base substitution causes cells to grow very poorly at low temperature $\left(18^{\circ} \mathrm{C}\right.$; Fig. $\left.2 \mathrm{~B}\right)$ but supports wild-type growth at normal $\left(30^{\circ} \mathrm{C}\right)$ and high $\left(37^{\circ} \mathrm{C}\right)$ temperatures (data not shown). The double mutant allele (snr6-A62G/A79G) is recessive lethal at all three temperatures (data not shown).

To directly assess the effect of the A62G mutation on 3 ' stem stability, we compared the melting temperatures $\left(T_{\mathrm{m}}\right)$ of wild type and mutant $3^{\prime}$ stems by using an in vitro DMS modification assay. Modification of the $C$ residues flanking the C-A pair at position 67/79 is diagnostic for the melting of the $3^{\prime}$ stem (Fig. 2C). Methylation of $\mathrm{C} 66$ and $\mathrm{C} 68$ is seen in the wild-type U6 RNA at a temperature $\sim 20^{\circ} \mathrm{C}$ lower than in the $\mathrm{A} 62 \mathrm{G}$ mutant U6 

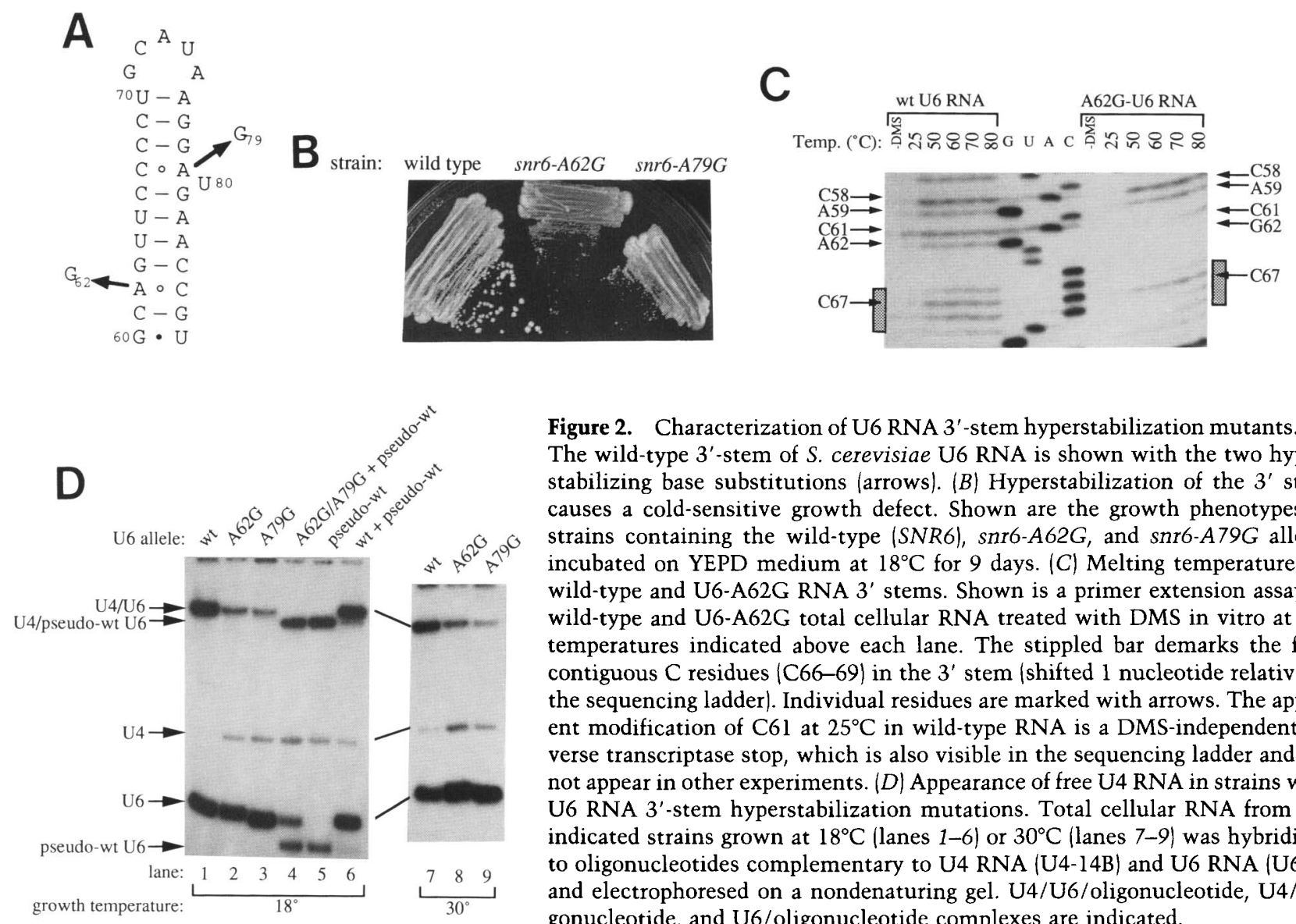

Figure 2. Characterization of U6 RNA 3 '-stem hyperstabilization mutants. $(A)$ The wild-type $3^{\prime}$-stem of $S$. cerevisiae U6 RNA is shown with the two hyperstabilizing base substitutions (arrows). $(B)$ Hyperstabilization of the $3^{\prime}$ stem causes a cold-sensitive growth defect. Shown are the growth phenotypes of strains containing the wild-type (SNR6), snr6-A62G, and snr6-A79G alleles incubated on YEPD medium at $18^{\circ} \mathrm{C}$ for 9 days. (C) Melting temperatures of wild-type and U6-A62G RNA 3' stems. Shown is a primer extension assay of wild-type and U6-A62G total cellular RNA treated with DMS in vitro at the temperatures indicated above each lane. The stippled bar demarks the four contiguous $C$ residues (C66-69) in the 3 ' stem (shifted 1 nucleotide relative to the sequencing ladder). Individual residues are marked with arrows. The apparent modification of $\mathrm{C} 61$ at $25^{\circ} \mathrm{C}$ in wild-type RNA is a DMS-independent reverse transcriptase stop, which is also visible in the sequencing ladder and did not appear in other experiments. (D) Appearance of free U4 RNA in strains with U6 RNA 3 '-stem hyperstabilization mutations. Total cellular RNA from the indicated strains grown at $18^{\circ} \mathrm{C}$ (lanes $1-6$ ) or $30^{\circ} \mathrm{C}$ (lanes $7-9$ ) was hybridized to oligonucleotides complementary to U4 RNA (U4-14B) and U6 RNA (U6-D) and electrophoresed on a nondenaturing gel. U4/U6/oligonucleotide, U4/oligonucleotide, and U6/oligonucleotide complexes are indicated.

RNA. Thus, the cold-sensitive A62G mutation enhances the stability of the $3^{\prime}$ stem.

If the melting of the hyperstabilized U6 RNA 3' stem becomes rate-limiting for U4/U6 snRNP assembly at low temperature, then there should be fewer U4/U6 RNA complexes and more uncomplexed $\mathrm{U} 4$ and $\mathrm{U} 6$ RNA in cells grown at $18^{\circ} \mathrm{C}$. To test this prediction, total cellular RNA was isolated from strains containing either the wild-type or mutant $\mathrm{U} 6$ genes grown at $18^{\circ} \mathrm{C}$, incubated with a ${ }^{32} \mathrm{P}$-labeled oligonucleotide complimentary to U4 and/or U6 RNAs, and the resulting RNA/oligonucleotide hybrids were resolved on a nondenaturing gel and visualized by autoradiography (Li and Brow 1993). Under the conditions of RNA extraction and assay, the $\mathrm{U} 4 / \mathrm{U} 6$ complex (wild type $T_{\mathrm{m}}=53^{\circ} \mathrm{C}$ ) remains intact. Nearly all of the U4 RNA is complexed to U6 RNA in the wild-type strain, whereas less than half is complexed in the two mutant strains containing either the snr6$A 62 G$ or the snr6-A79G alleles (Fig. 2D, lanes 1-3; quantitation was done on lanes with U4 oligonucleotide only; see Fig. 5D below). Given that U6 RNA is in excess of U4 RNA, the presence of free U4 RNA in the mutant strains is indicative of a U4/U6 assembly defect. When the amount of cellular RNA loaded in each lane is normalized using a U5 RNA probe, the total amount of U4 RNA in each preparation is the same (data not shown). Therefore, the appearance of free U4 RNA reflects a reduction in the amount of U4/U6 complex. Surprisingly, analysis of RNA from strains grown at $30^{\circ} \mathrm{C}$ yielded similar results (Fig. 2D, lanes 7-9), despite the absence of a growth phenotype at this temperature. Thus an approximately twofold reduction in the amount of U4/U6 snRNP is not sufficient to decrease the growth rate at $30^{\circ} \mathrm{C}$. Presumably, a higher concentration of U4/U6 snRNP is required for wild-type growth at $18^{\circ} \mathrm{C}$, or additional effects of the hyperstabilization mutation are manifested at low temperature.

Analysis of RNA from a strain containing the double mutant allele (snr6-A62G/A79G) and a pseudo-wild-type allele of SNR6, which provides a shortened but functional version of U6 RNA (Madhani et al. 1990), detects only U4/U6 complexes with the pseudo-wild-type mobility (Fig. 2D, lanes $4-6$ ). This result suggests that the double mutant U6 RNA does not assemble with U4 RNA and is consistent with the associated recessive lethal phenotype. Interestingly, the presence of free U4 RNA in a strain with only pseudo-wild-type U6 RNA (Fig. 2D, lane 5) indicates that pseudo-wild-type U6 RNA forms $\mathrm{U} 4 / \mathrm{U} 6$ complexes somewhat inefficiently at $18^{\circ} \mathrm{C}$. This could be a result of the lower amount of free U6 RNA in the pseudo-wild-type strain at $18^{\circ} \mathrm{C}$; or the structure of the $5^{\prime}$-stem/loop, which contains the only altered sequences in the pseudo-wild-type RNA, may influence formation of the U4/U6 snRNP. 

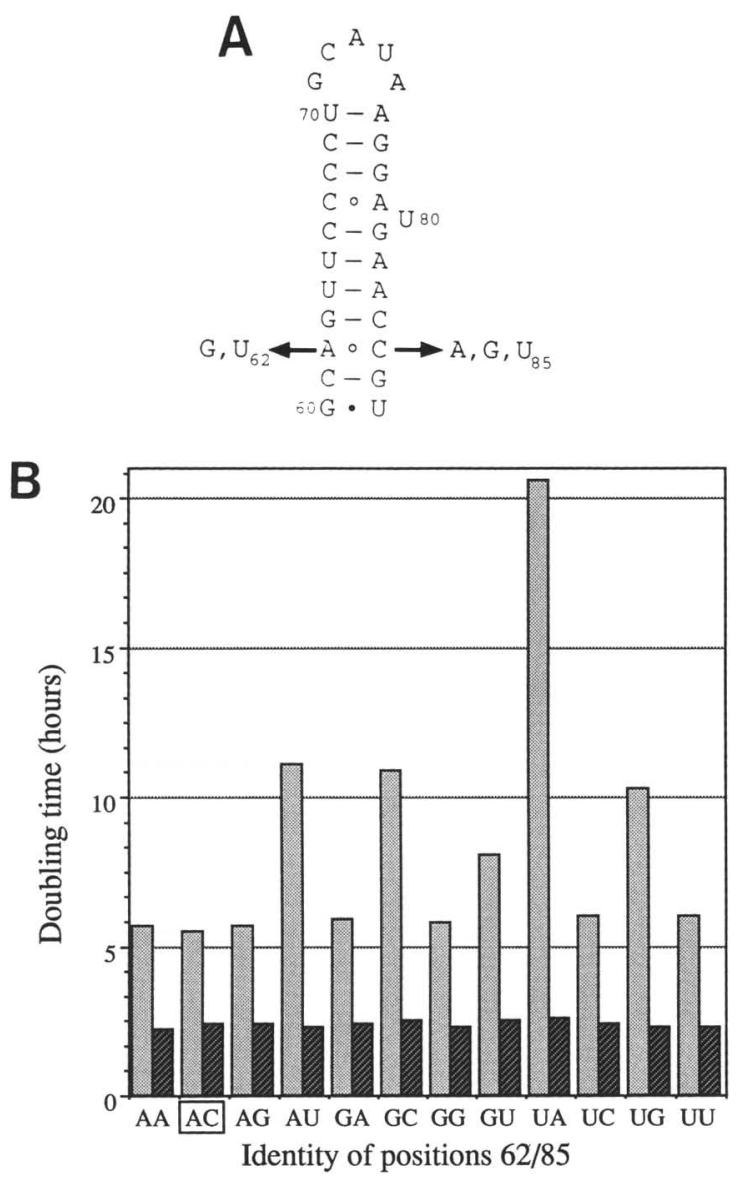

Figure 3. Correlation of cold sensitivity with the ability to form a base pair between positions 62 and $85 .(A)$ The wild-type $3^{\prime}$ stem of $S$. cerevisiae U6 RNA is shown with the base substitutions introduced at positions 62 and 85 (arrows). (B) Growth rate of strains harboring mutations at position 62 and 85 of SNR6 at $18^{\circ} \mathrm{C}$ (shaded) and $30^{\circ} \mathrm{C}$ (hatched) grown in YEPD media. The wild-type combination $(\mathrm{AC})$ is boxed. The graph shows the average time for a culture to double in optical density during log phase growth, for two independent cultures of each strain.

If the $\mathrm{A} 62 \mathrm{G}$ and $\mathrm{A} 79 \mathrm{G}$ mutations exert their deleterious effects by hyperstabilizing the $3^{\prime}$ stem, then other mutations that also stabilize the $3^{\prime}$ stem should have a similar phenotype. To test this prediction, we chose to examine one base pair in the stem extensively by introducing 12 different nucleotide combinations at positions 62 and 85 (Fig. $3 \mathrm{~A}$ ) on a LYS2-marked centromere plasmid into a strain (DMF101) containing gene disruptions for both the U4 and U6 genes and the wild-type copies of the U4 and U6 genes on HIS3- and URA3-marked plasmids, respectively. After selecting for loss of the URA3 plasmid by plating on medium containing 5-FOA, strains whose U6 RNA can form a Watson-Crick or G-U wobble base pair between positions 62 and 85 grow slowly at $18^{\circ} \mathrm{C}$, whereas strains with all other combinations exhibit wild-type growth (Fig. 3B). All strains grow normally at $30^{\circ} \mathrm{C}$. These results strongly suggest that the cold-sensitive growth defect is caused by the increased stability of the $3^{\prime}$ stem, as the cold sensitivity correlates with the ability to form hydrogen bonds between positions 62 and 85 and not with any particular nucleotide substitution at these positions. Interestingly, in addition to the effect of hyperstabilization, U6 alleles that have a $U$ at position 62 have a more severe growth defect than their equivalent reciprocal combinations (cf. U-A vs. A-U and U-G vs. G-Ul. The deleterious effect of $U$ at position 62 could be attributable to destabilization of the U4/U6 base-pairing (an A-U or G-U pair becomes a U-U pair; see Fig. 5B, below). However, the level of U4/U6 complex in a strain with snr6-A62U/C85A appears comparable to that in a snr6-A62G strain (data not shown). We therefore favor the notion that a $U$ at position 62 disrupts the interaction of the U6 RNA with some other component of the splicing machinery.
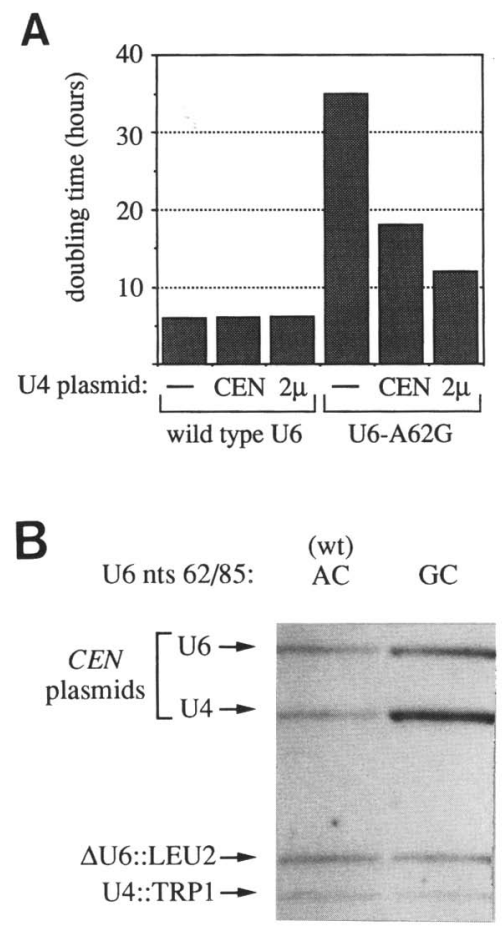

Figure 4. Partial suppression of the cold-sensitive growth phenotype by overexpression of U4 RNA. (A) The growth rate at $18^{\circ} \mathrm{C}$ of the hyperstabilization mutant snr6-A62G increases with additional copies of the U4 gene. Shown are the doubling times of wild-type (SNR6) or 3'-stem hyperstabilization mutant (snr6-A62G) strains with the U4 gene on the chromosome, without (-) or with additional copies of the U4 gene on either a $C E N$ or $2 \mu$ plasmid, grown at $18^{\circ} \mathrm{C}$ in YEPD media. $(B)$ The snr6-A62G mutation causes a selective advantage for increases in copy number of U4 and U6 centromere plasmids. Southern analysis of genomic DNA probed for the U4 and U6 genes shows an increase in copy number (see text) of U4 (pRS313-U4) and U6 (pRS317-U6) CEN plasmids in strains containing the mutant snr6-A62G allele (lane 2) as compared with wild-type U6 RNA (lane 1). Bands corresponding to both chromosomal gene disnuptions are also indicated as controls for the amount of DNA loaded on the gel. 
Partial suppression of the hyperstabilization phenotype by increased U4 gene dosage

If the growth phenotype of the hyperstabilzation mutants in the 3' stem is attributable to a U4/U6 assembly defect, then overexpression of U4 may suppress the growth defect by driving U4/U6 snRNP assembly via mass action. To determine whether this occurs, we introduced additional copies of the $\mathrm{U} 4$ gene on either a low-copy-number $(C E N)$ or high-copy-number $(2 \mu)$ plasmid into a wild-type strain and the snr6-A62G mutant strain and measured their growth rates at $18^{\circ} \mathrm{C}$ (Fig. 4A). As predicted, increasing the number of $\mathrm{U} 4$ genes in the snr6- $A 62 G$ strain increases the growth rate at $18^{\circ} \mathrm{C}$, consistent with increased expression of U4 RNA driving U4/U6 snRNP formation. Similar results were obtained with the snr6-A62U/C85A hyperstabilization mutant (data not shown). Examination of total cellular RNA (as done in Fig. 2D) obtained from the snr6-A62G strain with the $\mathrm{U} 4$ gene on a $2 \mu$ plasmid grown at $18^{\circ} \mathrm{C}$ showed that total U4 RNA level increased about fourfold and the amount of U4/U6 complex increased to at least that of the wild-type level (data not shown). Further evidence for partial suppression by overexpression of U4 RNA comes from Southern analysis of a strain that contains both the snr6-A62G allele and the wild-type U4 gene on CEN plasmids (Fig. 4B). The presence of the A62G mutation results in a twofold increase in U6 plasmid copy number and a fourfold increase in U4 plasmid copy number, in spite of the presence of centromeres in these plasmids. Again, similar results were obtained with the snr6-A62U/C85A hyperstabilization mutant /data not shown). Thus, cells that have increased the U4 and U6 plasmid copy numbers must have a selective advantage. Although additional copies of the U4 gene partially alleviate the cold-sensitive growth phenotype of the snr6$A 62 G$ mutation, the wild-type growth rate is not restored even though there is a wild-type level of U4/U6 complex present. This result again suggests that the U4/ U6 snRNP assembly defect is not solely responsible for cold-sensitive growth.

Genetic suppression analysis of a $3^{\prime}$ stem hyperstabilized U6 mutant

To obtain more insight into the defects caused by hyper- stabilizing the U6 RNA $3^{\prime}$ stem, we initiated the analysis of spontaneous suppressors of the snr6-A62G mutation carried on a $C E N$ plasmid. Suppressors were isolated by selecting for cells with approximately wild-type growth at $18^{\circ} \mathrm{C}$ on YEPD plates. Suppressor mutations in the U6 gene (cis-acting suppressors) were identified by sequencing the U6 RNA gene on the recovered CEN plasmid. Strains in which only the original A62G mutation was found must contain suppressor mutations in other genes (trans-suppressors). From 109 independent phenotypic revertants, 31 cis-acting suppressors were identified. Two are true revertants (G62A) and the remaining 29 correspond to 16 different single base substitutions and 1 single base insertion (Figs. 5A-C). Three of the suppressor mutations also confer temperature sensitivity: $\mathrm{C} 61 \mathrm{U}$ and $\mathrm{C} 66 \mathrm{U}$ result in slow growth at $37^{\circ} \mathrm{C}$ while the A insertion between bases 61 and 62 is lethal at $37^{\circ} \mathrm{C}$ (data not shown). Temperature sensitivity of the suppressor mutations in the absence of the primary $\mathrm{mu}$ tation (A62G) was not tested. Suppression of the coldsensitive growth defect by the 17 mutations was verified by retransforming the corresponding plasmids back into the original strain and scoring growth at $18^{\circ} \mathrm{C}$.

The cis-acting suppressors can be grouped into two classes: One class maps to the $3^{\prime}$ stem and the other class maps outside this region, mainly in the loop of the central stem. The mechanism of suppression for the first class can, in each case, be explained entirely by destabilization of a base pair in the $3^{\prime}$ stem. For example, the G-C base pair at position $62 / 85$ can be disrupted by six single base changes; we isolated five of these possible changes as spontaneous suppressor mutations. Analysis of U4/U6 complex formation in strains bearing suppressor mutations in the $3^{\prime}$ stem shows that in all cases the ratio of free to U6-complexed U4 RNA decreases significantly (from $55 \%$ in the $s n r 6-A 62 G$ strain to $<30 \%$ in the suppressor strains; Fig. $5 \mathrm{D}$ ), suggesting that partial reversal of the U4/U6 assembly defect contributes to cold-resistant growth. In contrast, several of the suppressor mutations that map outside of the $3^{\prime}$ stem (e.g., $\mathrm{A} 42 \mathrm{G}, \mathrm{C} 43 \mathrm{U}$, and $\mathrm{G} 55 \mathrm{U}$ ) do not significantly reduce the $\mathrm{U} 4$ to $\mathrm{U} 4 / \mathrm{U} 6$ ratio. These suppressors may act on another step in the splicing pathway (see Discussion). Interestingly, U4/U6 complex from some of the cis-acting suppressor strains (e.g., U38A, A40G, and G55U) has al-

Figure 5. Suppressors of the snr6-A62G cold-sensitive growth defect. (A) Spontaneous suppressors of the cold-sensitive growth phenotype of the snr6-A62G hyperstabilization mutant are indicated on the proposed U6 RNA secondary structure. In addition to the true revertant (G62A), there are 16 single base substitutions and 1 single base insertion (61A62). The number of times each was independently isolated is indicated by a subscripted number. $(B) \mathrm{U} 4 / \mathrm{U} 6 \mathrm{RNA}$ base-pairing model with the suppressors of $s n r 6-A 62 G$ indicated as in $A$. The model is modified from Brow and Guthrie (1988) to include additional base-pairing in the U4 RNA 5' stem/loop, based on unpublished data ( $\mathrm{Z}$. Li and $\mathrm{D}$. Brow). (C) U2/U6/pre-mRNA base-pairing model with the suppressors of snr6-A62G indicated as in $A$. The interactions depicted include the 5'-U2/3'-U6 (Hausner et al. 1990; Datta and Weiner 1991; Wu and Manley 1991) U2/central-U6 (Madhani and Guthrie 1992), U6/5'-splice site (Sawa and Abelson 1992; Sawa and Shimura 1992; Wassarman and Steitz 1992), and the U2/branchpoint (Parker et al. 1987) interactions. There are two slightly different models for the U6/5'-splice site interaction; the Wassarman and Steitz model is shown. The exons are shown as lightly shaded lines, and the intron as a dark line with the conserved residues indicated. (D) Efficiency of U4/U6 complex formation in snr6-A62G suppressors strains. Total cellular RNA from the indicated strains was hybridized to an oligonucleotide complementary to U4 RNA (U4-14B) and electrophoresed on a nondenaturing gel. U4/U6/oligonucleotide and U4/oligonucleotide complexes are indicated, and the percentage of uncomplexed U4 is displayed at right. The percentage of uncomplexed U4 for the G62U suppressor (denoted by the asterisk) was obtained from other gels in which two other RNA preparations were analyzed. 

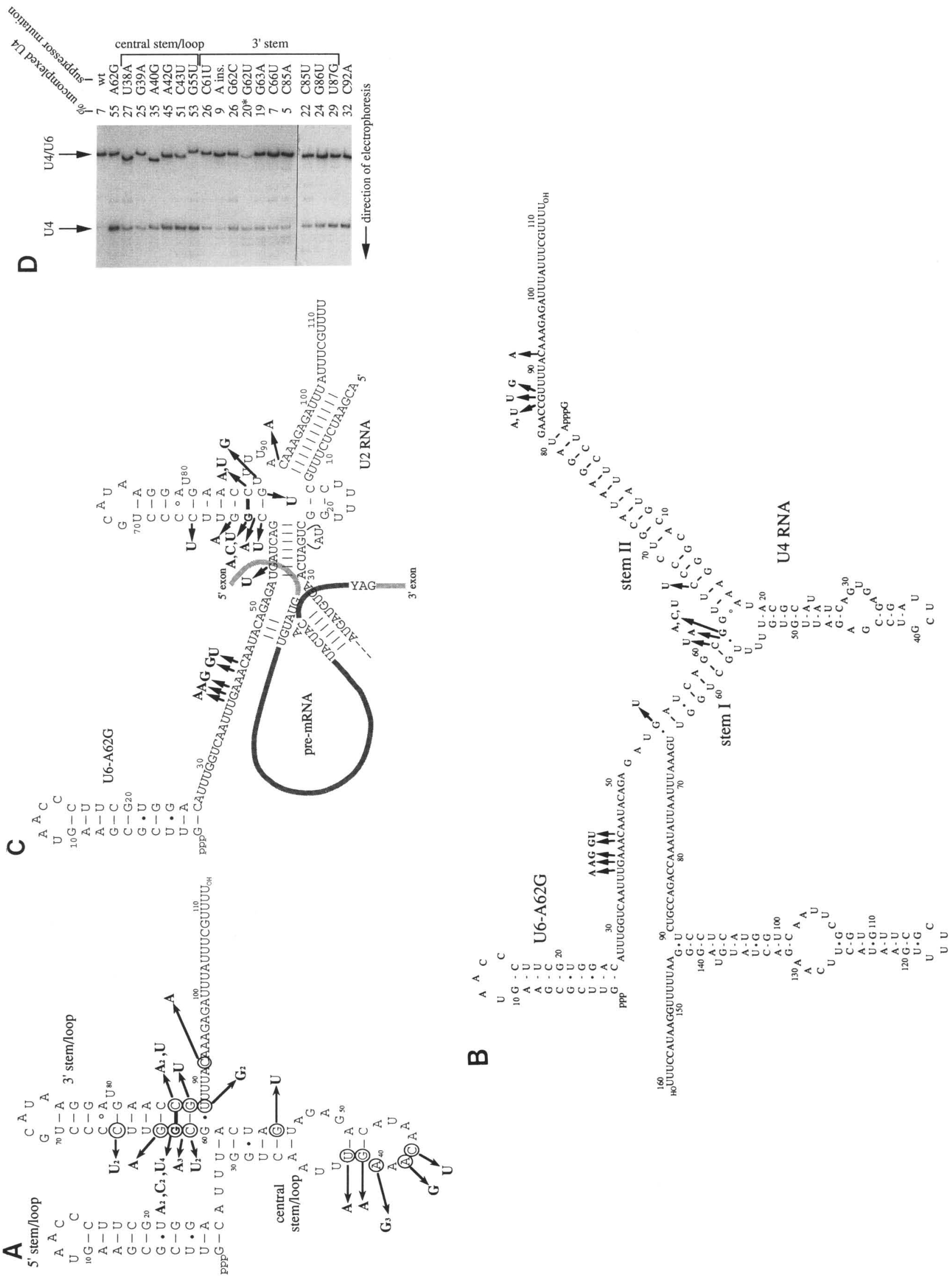
tered mobility in the nondenaturing gel system. Presumably, these suppressor mutations alter the deproteinized $\mathrm{U} 4 / \mathrm{U} 6$ complex structure. It is not clear whether this structural perturbation has any relationship to the ability to suppress the cold-sensitive growth phenotype.

\section{Discussion}

\section{U6 RNA secondary structure}

We present a secondary structure model of U6 RNA that consists of three stem/loops, a short joining region between the $5^{\prime}$ and central stems, and a $3^{\prime}$-terminal singlestranded tail (Fig. 1B). The central and $3^{\prime}$ stems are contiguous and so have the potential to stack coaxially, which is expected to contribute to their stability. Both the $5^{\prime}$ and $3^{\prime}$ stem/loops were proposed previously (Epstein et al. 1980; Harada et al. 1980) and are supported by an in vitro chemical modification study (Miura et al. 1983). Our DMS modification data provide strong evidence for their existence in vivo. The central stem/loop is novel and is mutually exclusive with a proposed extension of the $3^{\prime}$ stem that involves pairing between the central region of U6 RNA and its $3^{\prime}$ terminus (Epstein et al. 1980; Harada et al. 1980). Residues in the proposed central stem are substantially, but not fully, protected from methylation by DMS in vivo, so some fraction of the U6 RNA molecules must at least transiently be single-stranded in this region. The poor phylogentic conservation of the central stem suggests that if it exists, it is unique to yeast. Alternatively, proteins may play a larger role in stabilizing the central stem in other organisms. Irregular stems are common targets for RNA-binding proteins (for review, see Mattaj 1993) and the central stem/loop of U6 RNA encompasses a proposed binding site for the splicing factor Prp24 (Shannon and Guthrie 1991; see below).

The 3' stem in our model includes noncanonical A-C base pairs. In DNA, A-C base pairs are thought to be stabilized by two hydrogen bonds: In one the donor is the protonated $\mathrm{Nl}$ of adenine, and in the other the acceptor is N3 of cytosine (Hunter et al. 1986). A-C base pairs in RNA are proposed to have the same structure (Puglisi et al. 1990). Although the $\mathrm{pK}_{\mathrm{a}}$ of adenine $\mathrm{Nl}$ in free nucleosides is $\sim 4$, the $\mathrm{pK}_{\mathrm{a}}$ of adenine N1 in an A-C base pair embedded in a short DNA duplex is 6.6 (Wang et al. 1991), so A-C base pairs can form at physiological $\mathrm{pH}$. The sites of methylation of $A$ and $C$ residues by DMS are $\mathrm{N} 1$ of $\mathrm{A}$ and N3 of C, so A-C base-pair formation is expected to block modification of both A and $\mathrm{C}$ by DMS. Of the two proposed A-C base pairs in the U6 RNA 3' stem, one is strongly protected from DMS modification in vivo, and the other (adjacent to a bulged $U$ residue) is partially protected (Fig. 1; note that methylation of C 85 could not be assessed), consistent with interbase hydrogen bond formation via protonation of adenosine at physiological $\mathrm{pH}$. In light of the fact that nucleic acids have few acidic groups with $\mathrm{pK}_{\mathrm{a}} \mathrm{s}$ near physiological $\mathrm{pH}$, an intriguing possibility is that one or both of the A-C pairs in the U6 RNA 3' stem acts as a proton donor or acceptor during the splicing reaction. Although both A-C pairs are conserved in all U6 RNAs examined to date (with the exception of trypanosome U6 RNA), substitution of either one alone is not lethal, so their functions must be either redundant (the double mutant is lethal) or nonessential.

\section{Effects of hyperstabilization of the U6 RNA 3' stem}

Because the $3^{\prime}$ stem of U6 RNA must be unwound to allow the conserved core to base-pair with U4 RNA, hyperstabilization mutations are expected to inhibit U6 RNA function, particularly at low growth temperatures that disfavor thermal denaturation. Consistent with this expectation, six single and double point mutations in the $3^{\prime}$ stem that introduce a Watson-Crick or G-U wobble base pair in place of an A-C base pair result in slow growth relative to wild-type at $18^{\circ} \mathrm{C}$ (Figs. $2 \mathrm{~B}$ and $3 \mathrm{~B}$ ). In contrast, six single and double point mutations at positions 62 and 85 that do not result in formation of a Watson-Crick or G-U wobble base pair produce normal growth rates at $18^{\circ} \mathrm{C}$. Thus cold sensitivity correlates with base pair stability rather than nucleotide identity. RNA analysis of the snr6-A62G and snr6-A79G $3^{\prime}$-stem hyperstabilization mutant strains shows that U4/U6 complex formation is inhibited at $18^{\circ} \mathrm{C}$ (Fig. 2D). However, U4/U6 association is also inhibited at the permissive temperature, $30^{\circ} \mathrm{C}$, suggesting that an additional effect of the hyperstabilization mutations is contributing to slow growth at $18^{\circ} \mathrm{C}$. Alternatively, splicing could be inherently more sensitive to U4/U6 snRNP availability at low temperatures. Consistent with the former possibility, the cold-sensitive growth phenotype of the snr6$A 62 G$ and snr6-A62U/C85A hyperstabilization alleles is only partially suppressed by increased dosage of the wildtype U4 RNA gene (Fig. 4A), which results in wild-type levels of U4/U6 snRNP. Thus, a decrease in steady-state U4/U6 snRNP levels is partially, but not completely, responsible for the cold sensitivity of the $3^{\prime}$-stem hyperstabilzation mutants. We conclude that the competing intramolecular $\left(3^{\prime}\right.$ stem) and intermolecular (U4/U6) base-pairings of U6 RNA are finely balanced and can be influenced both by single base substitutions in U6 RNA and by changes in the concentration of U4 RNA. Furthermore, increased $3^{\prime}$ stem stability affects processes other than U4/U6 RNA association.

Wolff and Bindereif (1993) made mutations predicted to hyperstabilize the human U6 RNA $3^{\prime}$ stem and showed that these interfered with in vitro reconstitution of U4/U6 snRNP. However, they did not carry out systematic mutagenesis of any base pair in the stem to determine whether the assembly defect correlated with stability, nor did they determine whether the assembly defect could be suppressed by destablizing mutations elsewhere in the 3' stem. Therefore, they could not demonstrate that the assembly defect was attributable to hyperstabilization rather than some other effect of the mutation, such as disruption of the binding of a protein required for assembly. Nevertheless, their results are 
consistent with an inhibitory effect of U6 RNA $3^{\prime}$ stem hyperstabilization on U4/U6 snRNP assembly.

\section{Cold-sensitive mutations and RNA dynamics}

In previous mutational studies of yeast U2 (Ares and Igel 1990; Zavanelli and Ares 1991) and U4 (Shannon and Guthrie 1991) RNAs, as well as Escherichia coli 16S rRNA (Dammel and Noller 1993), cold sensitivity was associated with mutations that destabilize, rather than hyperstabilize, an intra- or intermolecular stem. This was a surprising result, as destabilizing mutations were expected to confer heat-sensitive (temperature-sensitive) phenotypes. In the case of U2 RNA and 16S RNA, the paradox was resolved on the identification of an alternative intramolecular stem whose formation is favored by the lack of competition from the destabilized mutant stem. That is, the relative stability of the alternative stem is increased by the mutations. In both $\mathrm{U} 2$ and $16 \mathrm{~S}$ RNAs, the alternative stem appears to trap the RNA in a less active or inactive conformation at low temperature; and in both cases, suppression of the growth phenotype can be achieved by mutations that destabilize the alternative stem (Zavanelli and Ares 1991; Dammel and Noller 1993; Zavanelli et al. 1994). Our results are therefore congruent with those of the Ares and Noller laboratories in that cold sensitivity appears to be, at least in part, attributable to hyperstabilization of an "inactive" (for U4/U6 snRNP assembly) conformation of U6 RNA relative to an "active" conformation, the U4/U6 intermolecular stems.

The cold-sensitive mutations that Shannon and Guthrie introduced into U4 RNA are located in stem II of the U4/U6 interaction region (see Fig. 5B) and destabilize the intermolecular helix (Shannon and Guthrie 1991). By analogy to the cold-sensitive mutations in U2 RNA and 16S RNA, the effect of these mutations can be understood as being attributable to the relative hyperstabilization of an alternative intramolecular stem in $\mathrm{U} 4$ and/ or U6 RNA. Clearly the $3^{\prime}$ stem of U6 RNA is a good candidate for such an alternative structure. It is therefore surprising that four independent spontaneous mutations in the U6 gene that suppress a cold-sensitive mutation in the stem II region of U4 RNA all lie outside of the $3^{\prime}$ stem (Shannon and Guthrie 1991; see below). Perhaps 3' stem destabilization mutations are detrimental to U6 RNA stability and/or function in an otherwise wild-type RNA /as opposed to the A62G hyperstabilization mutant; Fig. $5 \mathrm{~A}, \mathrm{Cl}$, and so potential suppressors of the U4 mutation were selected against due to their own growth phenotypes. This hypothesis is supported by our observation that three destabilizing mutations in the U6A62G $3^{\prime}$ stem have temperature-sensitive growth phenotypes and by the recent finding that destabilizing mutations in the human U6 RNA 3' stem block step I of splicing in vitro (Wolff and Bindereif 1993). However, we cannot exclude the possibility that the cold sensitivity of Shannon and Guthrie's U4 mutant strains is attributable to formation of some other alternative structure.
Cis-acting suppression of a $3^{\prime}$ stem hyperstabilization mutation by two classes of mutations

From 109 independent phenotypic revertants of the snr6A62G strain, 31 cis-acting suppressors containing 18 different SNR6 point mutations were identified: the true reversion (G62A), 16 single base substitutions, and 1 single base insertion (Fig. 5A). The cis-acting suppressor mutations can be grouped into two classes. The mutations in one class (hereafter called class I) map to the $3^{\prime}$ stem, are expected to destabilize the stem, and result in a substantial decrease in the ratio of free U4 RNA to U4/U6 RNA complex (5-29\% free U4 as opposed to 55\% in the A62G mutant). Mutations of the other class (class II) map to the central stem/loop and the $3^{\prime}$ tail and result in a more modest change in the proportion of U4 RNA not complexed to U6 RNA (25-53\%).

The mechanism of suppression by the class I mutations is most likely the return of the $3^{\prime}$-stem to approximately wild-type stability. Except for the U87G mutation, all of the class I substitutions disrupt a G-C base pair and so are expected to compensate for the primary mutation, which creates a G-C pair. Furthermore, a single-base bulge caused by the A insertion class I suppressor would increase the free energy of the $3^{\prime}$ stem by an amount that should also be sufficient to compensate for the primary mutation (Freier et al. 1986). Our class I suppressors are therefore analogous to the suppressors of cold-sensitive mutations in U2 and 16S RNAs, which are thought to suppress via destabilization of an alternative conformation of the RNA (Dammel and Noller 1993; Zavanelli et al. 1994). As is expected for the proposed mechanism, the class I suppressors increase the level of U4/U6 RNA complex in the snr6-A62G strain (Fig. 5D). It is likely, however, that the increase in U4/U6 snRNP levels is not the sole cause for reversion of the low temperature growth defect, as overexpression of wild-type U4 RNA in a snr6-A62G strain, which results in wildtype levels of U4/U6 snRNP, still does not allow wildtype growth at $18^{\circ} \mathrm{C}$ (Fig. 4A). Steps in the splicing cycle other than U4/U6 snRNP assembly may also be inhibited by hyperstabilization of the $3^{\prime}$ stem. For example, if the $3^{\prime}$ stem reforms after U4 RNA dissociates from the spliceosome (see below), alteration of its structure may interfere with the catalytic steps of splicing or with disassembly of snRNPs from the lariat intron.

The mechanism of suppression by the class II mutations is less obvious. Their location and their failure, at least in some cases, to significantly correct the U4/U6 complex assembly defect suggests that they act differently than the class I suppressors. A striking feature of our class II suppressors is their colocalization with the four recessive mutations in the U6 RNA gene that suppress the cold-sensitive phenotype of the G14C stem II destabilizing mutation in U4 RNA (Shannon and Guthrie 1991). One of Shannon and Guthrie's suppressors (A40G) is identical to a class II mutation, two (U38C and $\mathrm{C} 43 \mathrm{G}$ ) are at the same position as class II mutations (U38A and C43U), and one (A91G) is adjacent to a class 
II mutation (C92A). Because the U4-G14C mutation destabilizes the U4/U6 interaction, it is reasonable to expect that our class II suppressors act by the same mechanism as Shannon and Guthrie's colocalizing suppressors. They propose that the recessive suppressors in SNR6 weaken the association of a splicing factor, Prp24, with U6 RNA, and that dissociation of Prp24 from U6 RNA is a prerequisite for base-pairing with U4 RNA. That is, the competing interaction that leads to cold sensitivity is, in this case, proposed to be an RNA-protein interaction rather than an RNA-RNA interaction. In support of this model, Shannon and Guthrie also isolated suppressors of the U4-G14C mutation in the putative RNA-binding domain of Prp24. In this regard, it will be interesting to determine whether any of our 78 trans: acting suppressor mutations are in the Prp24 gene. However, the failure of several of the class II mutations to increase the level of U4/U6 RNA complex in cellular RNA suggests that these suppressors may act on steps subsequent to U4/U6 snRNP assembly. (We cannot exclude the unlikely possibility that the class II suppressors alter U4/U6 snRNP assembly in a manner not detected in our assay.) It may be significant that several of the class II mutations alter the structure of the U4/U6 RNA complex sufficiently to cause it to run with altered mobility on native gels (Fig. 5D). Further analysis of the class II suppressors will be required before their mechanism of action is clear.

\section{Is the $3^{\prime}$ stem of U6 RNA present in the active} spliceosome?

Work from a number of laboratories has identified basepairing interactions between U6 RNA, U2 RNA, and the pre-mRNA that are believed to occur in the active spliceosome. Because U4 RNA appears to dissociate from the spliceosome prior to the catalytic steps of splicing, U6 RNA would be free to reform the $3^{\prime}$ stem at this point in the splicing cycle. Although we have no evidence that this occurs, formation of the $3^{\prime}$ stem of U6 RNA would juxtapose the two regions of U6 RNA that base-pair with U2 RNA (Fig. 5C), as also noted by others (Madhani and Guthrie 1992; Wolff and Bindereif 1993). Hyperstabilization of the 3' stem may therefore also favor formation of the U2/U6 RNA complex, a possible consequence of which might be premature formation of the U2/U6 complex, or failure of the U2/U6 complex to dissociate after splicing has occurred. Interestingly, two of the class II suppressors (G55U and $\mathrm{C} 92 \mathrm{~A}$ ) are expected to weaken U2/U6 base-pairing (Fig. 5C). If U2/U6 destabilization is the mechanism of suppression for these two mutations, we would expect to find similarly destabilizing mutations in U2 RNA among our trans-acting suppressors. We are now determining the locus and identity of each of the 78 trans-acting suppressor mutations.

\section{Materials and methods}

\section{Plasmid constructions}

p-539H6 contains 1169 bp of SNR6 $(-539$ to +630 relative to the start of transcription) and has been described previously (Brow and Guthrie 1990). p-539H6-A62G, p-539H6-A79G, and p-539H6-A62G/A79G were generated by oligonucleotide-directed mutagenesis of p-539H6. p-539H6 was transformed into E. coli dut ${ }^{-}$ung $^{-}$mutant RZ1032, and single-stranded uracil containing DNA was obtained as described /Vieira and Messing 1987). Mutagenesis was performed essentially as described (Kunkel et al. 1987) using oligonucleotides U6-A62G and/or U6-A79G. The mutagenized DNA was then transformed into $E$. coli and the resulting clones were sequenced by the dideoxy method using Sequenase (U.S. Biochemical). The mutant alleles of SNR6 were cloned into the yeast shuttle vector pSE358 (CEN4, ARS1, TRP1; derivative of pUN10; Elledge and Davis 1988 ) by isolating the EcoRI-SphI fragment from each allele and ligating it into EcoRI-SphI-cut pSE358. The mutant pSE358U6-A62U was obtained as a suppressor (see below). Wild-type SNR6, as well as mutants snr6-A62G and snr6-A62U, were also cloned into yeast shuttle vector pRS317 (CEN6, ARSH4, LYS2; Sikorski and Boeke 1991) by isolating the EcoRI-PstI fragment from each allele and ligating into EcoRI-PstI-cut pRS317. These three SNR6 alleles in the pRS317 vector were used for directed mutagenesis (as above) using oligonucleotide U6-C85D to make all combinations at position 85 . YCp50-39D6 was constructed by ligating the EcoRI-HindIII fragment of $-39 \mathrm{D} 6(-39$ to +250 of SNR6) into EcoRI-HindIII-cut YCp50 (CEN4, ARS1, URA3).

pRS426-U4 was constructed by cloning the EcoRI-BamHI fragment from YCp50-SNR14 (Shannon and Guthrie 1991) into EcoRI-BamHI-cut shuttle vector pRS426 $(2 \mu$ ORI, URA3; Christianson et al. 1992). pRS313-U4 was constructed by ligating the EcoRI-BamHI fragment from YCp50-SNR14 into EcoRI-BamHI-cut shuttle vector pRS313 (CEN6, ARSH4, HIS3; Sikorski and Hieter 1989).

\section{Plasmid shuffle assay}

Mutant alleles of SNR6 cloned into pSE358 or pRS317 were tested for their ability to function as the sole U6 RNA gene in the cell by transformation (Ito et al. 1983) into a yeast strain containing an insertion in (DAB016; MATa, leu2, trp1, his4, ura3, snr6::LEU2, [YCpEP6 (YCp50 with SNR6)]; Brow and Guthrie 1990) or a replacement of (DMF101) the chromosomal copy of SNR6. To obtain DMF101, MWK033 (MATa, his3, leu2, trp1, ura3, met2, lys2, can1, ade2, $\Delta$ snr6::LEU2 [pRS317539H6], a derivative of MWK023; Eschenlauer et al. 1993) was mated to YKS2 (MATa, trp1, his3, ura3, ade2, lys2, snr14::TRP1 [YCp50-SNR14]; Shannon and Guthrie 1991). After sporulation of the diploid, a tetrad in which all four spores had the LEU2 marker (confirming segregation of $\triangle s n r 6:$ LEU2 from chromosomal $L E U 2$ ) was screened for growth on medium lacking tryptophan and for sensitivity to $\alpha$-aminoadipate (Chatoo at al. 1979|, which identifies both the U4 and U6 gene disruptions. pRS313-U4 (HIS3) was introduced into a $\operatorname{Trp}^{+}, \alpha$-aminoadipate-sensitive spore, and the resulting strain was plated on 5-FOA to select for loss of YCp50-SNR14 (Sikorski and Boeke 1991). YCp50-39D6 was then introduced, and the resulting strain was plated on $\alpha$-aminoadipate to select for loss of pRS317-539H6 to create DMF101. Trp ${ }^{+}$or $\mathrm{Lys}^{+}$transformants of DAB016 and DMF101, respectively, were streaked on plates containing 5-FOA, which selects for loss of the $U R A 3$ plasmid carrying the wild-type allele of $S N R 6$. Strains that live on 5-FOA plates contain functional SNR6 alleles on the TRP1 or LYS2 plasmid; those that die do not. The only SNR6 allele found to be lethal (snr6-A62G/A79G) was transformed into a yeast strain (MWK003, a derivative of DAB016) containing a pseudo-wildtype allele of $S N R 6$ on YCp50 (YCp50- $\Psi \mathrm{wt}$ ) as its only copy of SNR6. The pseudo-wild-type SNR6 has the first 25 bp of the 
coding region replaced with the first 12 bp of the RNA coding region of the Schizosaccharomyces pombe U6 gene (Madhani et al. 1990) and was a kind gift from Rémy Bordonné and Christine Guthrie (University of California, San Franciso). Thus, the pseudo-wild-type U6 RNA gives a shorter RNA that can be distinguished from the RNA made from transcripts of mutant SNR6 genes in a solution hybridization assay (see below).

\section{Oligonucleotides}

The olidonucleotides used in this study are as follows: U6A62G, 5'-GCAGGGGAACCGCTGATCATC; U6-A79G, 5'-GTAAAACGGTTCACCCTTATGCAGG; U6-C85D, 5'-CTTTGTAAAACDGTTCATCCTTATG $(\mathrm{D}=33.3 \% \mathrm{~A}, \mathrm{G}$, and $\mathrm{T})$; U6-D, 5'-AAAACGAAATAAATCTCTTTG; U6-C, 5'-AAAACGAAATAAATCTC; U4-14B, 5'-AGGTATTCCAAAAATTCCC; U5B, 5'-AAGTTCCAAAAAATATGGCAAGC.

\section{In vivo DMS modification assay}

DMS modification of yeast cells was done as described by Ares and Igel (1990). Total cellular RNA was prepared by the guanidinium thiocyanate method (Wise et al. 1983). Primer extension analysis using oligonucleotides U6-C and U6-D was as described by Eschenlauer et al. (1993).

\section{In vitro DMS modification: $\mathrm{T}_{m}$ analysis}

Cellular RNA (50 $\mu \mathrm{g}$ ) (Wise et al. 1983) from strains containing the wild-type and A62G-U6 RNAs was resuspended in $1 \mathrm{ml}$ of DMS modification buffer ( $150 \mathrm{~mm} \mathrm{NaCl}, 50 \mathrm{mM} \mathrm{Na}$ cacodylate at $\mathrm{pH} 7.0$, and $0.1 \mathrm{~mm}$ EDTA) and aliquoted into 5 microcentrifuge tubes. The tubes were equilibrated to temperature $\left(25^{\circ}\right.$, $50^{\circ}, 60^{\circ}, 70^{\circ}$, or $80^{\circ} \mathrm{C}$ ) for $5 \mathrm{~min}$. One microliter of $12.5 \%$ DMS (vol/vol in ethanol) was added (the control reactions received nothing/ and incubated for $10 \mathrm{~min}$. The reaction was stopped with $50 \mu \mathrm{l}$ of $5 \times$ DMS-stop solution $(1.5 \mathrm{M} \mathrm{NaOAc}, 0.1 \mathrm{~mm}$ EDTA, $1.0 \mathrm{M} 2$-mercaptoethanol, $0.1 \mathrm{mg} / \mathrm{ml}$ of $E$. coli tRNA, and $1.0 \mathrm{M}$ Tris-OAc at $\mathrm{pH} 7.5 /$ and ethanol precipitated for primer extension analysis as above.

\section{RNA analysis}

Total cellular RNA was obtained as described previously /Treco 1989). All cells were grown at the indicated temperature in YEPD broth except for strains containing the pseudo-wild-type allele of SNR6, which were grown in synthetic media lacking uracil, leucine, and tryptophan. Roughly $5 \mu \mathrm{g}$ (based on $\mathrm{OD}_{280}$ readings) of RNA was used for each solution hybridization. The solution hybridizations were done essentially as in Li and Brow (1993). Briefly, the RNA was desiccated and resuspended in $6 \mu \mathrm{l}$ of buffer + oligonucleotide $(150 \mathrm{~mm} \mathrm{NaCl}, 50 \mathrm{~mm}$ Tris- $\mathrm{Cl}$ at $\mathrm{pH}$ 7.5, $1 \mathrm{~mm}$ EDTA, 100 fmoles ${ }^{32}$ P-labeled oligonucleotide U6-D, U4-14B, or U5-D) and incubated for $15 \mathrm{~min}$ at $37^{\circ} \mathrm{C}$. The reaction was stopped by placing the samples on dry ice, and $6 \mu \mathrm{l}$ of loading buffer ( $10 \%$ glycerol and $0.05 \%$ xylene cyanol) was added before loading the samples, which were electrophoresed at $350 \mathrm{~V}$ on a $10-\mathrm{cm}$-tall, $1-\mathrm{mm}$-thick, $9 \%$ polyacrylamide nondenaturing gel (30:1 acrylamide/bisacrylamide (BDH Electran) in $50 \mathrm{~mm}$ Tris-borate at $\mathrm{pH} 8.3$ and $1 \mathrm{~mm}$ EDTA) for $\sim 1.5 \mathrm{hr}$. The oligonucleotides were end-labeled with $\left[\gamma^{32} \mathrm{P}\right]$ ATP using T4 polynucleotide kinase (U.S. Biochemical) and were separated from unincorporated nucleotide on a 1-ml Bio-Gel P-30 column (Bio-Rad). Gels were exposed to X-Omat AR5 film (Kodak) with or with out a Cronex Lightning-Plus screen (DuPont). Gels were quantitated using an AMBIS $\beta$-imager or by densitometry of autoradiograms with an Apple OneScanner and Scan Analysis software (Biosoft).

\section{Growth curves}

An overnight saturated culture was diluted into YEPD to an $\mathrm{OD}_{600}$ of $\sim 0.05$, and absorbance measurements were taken (at least 7) from an absorbance of 0.1-1.0. Doubling times were obtained from a best fit line obtained by plotting time versus log (absorbance) using the graphing program Cricket Graph (version 1.3.2).

\section{Southern analysis}

Genomic DNA was isolated as described (Hoffman and Winston 1987 from yeast strains grown at $18^{\circ} \mathrm{C}$ in YEPD. Approximately 2-4 $\mu \mathrm{g}$ of EcoRI-cut genomic DNA was electrophoresed for 15 hr at $50 \mathrm{~V}$ on a $27-\mathrm{cm} 0.7 \%$ agarose gel in $50 \mathrm{mM}$ Tris-borate at $\mathrm{pH} 8.3$ and $1 \mathrm{~mm}$ EDTA. DNA was transferred to a Zeta-probe membrane as recommended by the manufacturer (Bio-Rad). The membrane was probed with randomly primed DNA made from a BsmI-HindIII fragment of $\mathrm{p}-539 \mathrm{H} 6$ containing sequences 200 $600 \mathrm{bp}$ downstream of the U6 RNA coding region and from a EcoRI-BamHI fragment of pBS-109 (Shannon and Guthrie 1991) containing $550 \mathrm{bp}$ of the U4 gene and flanking sequences.

\section{Genetic suppression analysis}

Spontaneous independent suppressors of the cold-sensitive growth defect of the snr6-A62G mutation were generated by plating on YEPD medium $250 \mu \mathrm{l}$ of a 2-ml YEPD overnight culture of single colonies of the snr6-A62G strain (snr6::LEU2, leu2, ura3, his4, trp1, [pSE358-U6-A62G]). After $\sim 2$ weeks at $18^{\circ} \mathrm{C}, 1-4$ colonies growing above background were selected (of the 1-10 colonies/plate) and streak-purified, once at $18^{\circ} \mathrm{C}$ and once at $30^{\circ} \mathrm{C}$. Cis-acting suppressors were identified by isolating DNA (Hoffman and Winston 1987) from these suppressor strains and transforming it into $E$. coli strain DH5 $\alpha$. Plasmids were isolated by the boiling lysis method, and the U6 gene was sequenced. Plasmid-linked suppression was verified by retransforming plasmids into DAB016 and scoring for growth at $18^{\circ} \mathrm{C}$ after the wild-type copy of $S N R 6$ was removed by plating on 5-FOA.

\section{Acknowledgments}

We thank Michael Kaiser, Karen Shannon, Rémy Bordonné, and Christine Guthrie for plasmid DNAs and/or yeast strains. We are grateful to Eric Steinmetz, Karen Shannon, and James Dahlberg for comments on the manuscript and to members of the Brow laboratory for discussions. This work was supported by an award from the Searle Scholars Program/The Chicago Community Trust to D.A.B. D.M.F. was a predoctoral trainee of a National Institutes of Health Cellular and Molecular Biology training grant (GM07215).

The publication costs of this article were defrayed in part by payment of page charges. This article must therefore be hereby marked "advertisement" in accordance with 18 USC section 1734 solely to indicate this fact.

\section{References}

Ares, M. Jr. and A.H. Igel. 1990. Lethal and temperature-sensitive mutations and their suppressors identify an essential 
structural element in U2 small nuclear RNA. Genes \& Dev. 4: $2132-2145$

Bringmann, P., B. Appel, J. Rinke, R. Reuter, H. Theissen, and R. Lührmann. 1984. Evidence for the existence of snRNAs U4 and U6 in a single ribonucleoprotein complex and for their association by intermolecular base pairing. $E M B O J$. 3: 1357-1363.

Brow, D.A. and C. Guthrie. 1988. Spliceosomal U6 RNA is remarkably conserved from yeast to mammals. Nature 334: 213-218.

- 1989. Splicing a spliceosomal RNA. Nature 337: 14-15. 1990. Transcription of a yeast U6 snRNA gene requires a polymerase III promoter element in a novel position. Genes \& Dev. 4: 1345-1356.

Chatoo, B.B., F. Sherman, D.A. Azubalis, T.A. Fjellstedt, D. Mehnert, and M. Ogur. 1979. Selection of lys2 mutants of the yeast Saccharomyces cerevisiae by the utilization of $\alpha$-aminoadipate. Genetics 93: 51 .

Cheng, S.-C. and J. Abelson. 1987. Spliceosome assembly in yeast. Genes \& Dev. 1: 1014-1027.

Christianson, T.W., R.S. Sikorski, M. Dante, J.H. Shero, and P. Hieter. 1992. Multifunctional yeast high-copy-number shuttle vectors. Gene 110: 119-122.

Dammel, C.S. and H.F. Noller. 1993. A cold-sensitive mutation in $16 \mathrm{~S}$ rRNA provides evidence for helical switching in ribosome assembly. Genes \& Dev. 7: 660-670.

Datta, B. and A.M. Weiner. 1991. Genetic evidence for base pairing between U2 and U6 snRNAs in mammalian mRNA splicing. Nature 352: 821-824.

Elledge, S.J. and R.W. Davis. 1988. A family of versatile centromeric vectors designed for use in the sectoring-shuffle mutagenesis assay in Saccharomyces cerevisiae. Gene 70: 303312.

Epstein, P., R. Reddy, D. Henning, and H. Busch. 1980. The nucleotide sequence of nuclear U6 (4.7S) RNA. I. Biol. Chem. 255: 8901-8906.

Eschenlauer, J.B., M.W. Kaiser, V.L. Gerlach, and D.A. Brow. 1993. Architecture of a yeast U6 RNA gene promoter. Mol. Cell. Biol. 13: 3015-3026.

Fabrizio, P. and J. Abelson. 1990. Two domains of yeast U6 small nuclear RNA required for both steps of nuclear precursor messenger RNA splicing. Science 250: 404-409.

Freier, S.M., R. Kierzek, J.A. Jaeger, N. Sugimoto, M.H. Caruthers, T. Neilson, and D.H. Turner. 1986. Improved freeenergy parameters for predictions of RNA duplex stability. Proc. Natl. Acad. Sci. 83: 9373-9377.

Green, M.R. 1991. Biochemical mechanisms of constitutive and regulated pre-mRNA splicing. Annu. Rev. Cell Biol. 11: 2026-2034.

Guthrie, C. 1991. Messenger RNA splicing in yeast: Clues to why the spliceosome is a ribonucleoprotein. Science 253: $157-163$.

Guthrie, C. and B. Patterson. 1988. Spliceosomal snRNAs. Annu. Rev. Genet. 22: 387-419.

Harada, F., N. Kato, and S. Nishimura. 1980. The nucleotide sequences of nuclear $4.8 \mathrm{~S}$ RNA of mouse cells. Biochem. Biophys. Res. Commun. 95: 1332-1340.

Hashimoto, C. and J.A. Steitz. 1984. U4 and U6 RNAs coexist in a single small nuclear ribonucleoprotein particle. Nucleic Acids Res. 12: 3283-3293.

Hausner, T.-P., L.M. Giglio, and A.M. Weiner. 1990. Evidence for base-pairing between mammalian $\mathrm{U} 2$ and $\mathrm{U} 6$ small nuclear ribonucleoprotein particles. Genes \& Dev. 4: 21462156.

Hoffman, C.S. and F. Winston. 1987. A ten-minute DNA preparation from yeast efficienly releases autonomous plasmids for transformation of Escherichia coli. Gene 57: 267-272.

Hunter, W.N., T. Brown, N.N. Anand, and O. Kennard. 1986. Structure of an adenine-cytosine base pair in DNA and its implications for mismatch repair. Nature 320: 552-555.

Inoue, T. and T. Cech. 1985. Secondary structure of the circular form of the Tetrahymena rRNA intervening sequence: A technique for RNA structure analysis using chemical probes and reverse transcriptase. Proc. Natl. Acad. Sci. 82: 648-652.

Ito, H., Y. Fukuda, K. Murata, and A. Kimura. 1983. Transformation of intact yeast cells treated with alkali cations. $J$. Bacteriol. 153: 163-168.

Konarska, M.M. and P.A. Sharp. 1987. Interactions between small ribonucleoprotein particles in formation of spliceosomes. Cell 49: 763-774.

Kunkel, T.A., J.D. Roberts, and R.A. Zakour. 1987. Rapid and efficient site-specific mutagenesis without phenotypic selection. Methods Enzymol. 154: 367-383.

Lamond, A.I., M.M. Konarska, P.J. Grabowski, and P.A. Sharp. 1988. Spliceosome assembly involves the binding and release of U4 small nuclear ribonucleoprotein. Proc. Natl. Acad. Sci. 85: 411-415.

Li, Z. and D.A. Brow. 1993. A rapid assay for quantitative detection of specific RNAs. Nucleic Acids Res. 21: 4645-4646.

Madhani, H.D. and C. Guthrie. 1992. A novel base-pairing interaction between $\mathrm{U} 2$ and $\mathrm{U} 6$ snRNAs suggests a mechanism for the catalytic activation of the spliceosome. Cell 71: 803-817.

Madhani, H.D., R. Bordonné, and C. Guthrie. 1990. Multiple roles for U6 snRNA in the splicing pathway. Genes \& Dev. 4: 2264-2277.

Mattaj, I.W. 1993. RNA recognition: A family matter? Cell 73: $837-840$.

Miura, K., S. Tsuda, F. Harada, and T. Ueda. 1983. Chemical modification of cytosine residues of U6 snRNA with hydrogen sulfide. Nucleic Acids Res. 11: 5893-5901.

Moazed, D., S. Stern, and H.F. Noller. 1986. Rapid chemical probing of conformation in $16 \mathrm{~S}$ ribosomal RNA and $30 \mathrm{~S}$ ribosomal subunits using primer extension. I. Mol. Biol. 187: 399-416.

Mottram, J., K.L. Perry, P.M. Lizardi, R. Lührmann, N. Agabian, and R.G. Nelson. 1989. Isolation and sequence of four small nuclear U RNA genes of Trypanosoma brucei subsp. brucei: Identification of the U2, U4, and U6 RNA analogs. Mol. Cell. Biol. 9: 1212-1223.

Parker, R., P. Siliciano, and C. Guthrie. 1987. Recognition of the TACTAAC box during mRNA splicing in yeast involves base pairing to the U2-like snRNA. Cell 49: 229-239.

Peebles, C.L., P.S. Perlman, K.L. Mecklenburg, M.L. Petrillo, J.H. Tabor, K.A. Jarrell, and H.-L. Cheng. 1986. A self-splicing RNA excises an intron lariat. Cell 44: 213-223.

Pikielney, C.W., B.C. Rymond, and M. Rosbash. 1986. Electrophoresis of ribonucleoproteins reveals an ordered assembly pathway of yeast splicing complexes. Nature 324: 341-345.

Puglisi, J.D., J.R. Wyatt, and I. Tinoco Jr. 1990. Solution conformation of an RNA hairpin loop. Biochemistry 29: 42154226.

Rinke, J., A. Bernd, M. Digweed, and R. Lührmann. 1985. Localization of a base-paired interaction between small nuclear RNAs U4 and U6 in intact U4/U6 ribonucleoprotein particles by psoralen cross-linking. J. Mol. Biol. 185: 721-731.

Roiha, H., E.O. Shuster, D.A. Brow, and C. Guthrie. 1989. Small nuclear RNAs from budding yeasts: phylogenetic comparisons reveal extensive size variation. Gene 82: 137-144.

Rymond, B.C. and M. Rosbash. 1992. Yeast pre-mRNA splicing. The molecular and cellular biology of the yeast Saccharomyces: Gene expression, (eds. E.W. Jones, J.R. Pringle, and 
J.R. Broach/pp. 143-192. Cold Spring Harbor Laboratory Press, Cold Spring Harbor, New York.

Sawa, H. and J. Abelson. 1992. Evidence for a base-pairing interaction between U6 small nuclear RNA and the $5^{\prime}$ splice site during the splicing reaction in yeast. Proc. Natl. Acad. Sci. 89: 11269-11273.

Sawa, H. and Y. Shimura. 1992. Association of U6 snRNA with the $5^{\prime}$ splice site region of pre-mRNA in the spliceosome. Genes \& Dev. 6: 244-254.

Shannon, K.W. and C. Guthrie. 1991. Suppressors of a U4 snRNA mutation define a novel U6 snRNP protein with RNAbinding motifs. Genes \& Dev. 5: 773-785.

Shumyatsky, G. and R. Reddy. 1993. Compilation of small RNA sequences. Nucleic Acids Res. 21: 3017.

Sikorski, R.S. and J.D. Boeke. 1991. In vitro mutagenesis and plasmid shuffling: From cloned gene to mutant yeast. Methods Enzymol. 194: 302-329.

Sikorski, R.S. and P. Hieter. 1989. A system of shuttle vectors and yeast host strains designed for efficient manipulation of DNA in Saccharomyces cerevisiae. Genetics 122: 19-27.

Siliciano, P.G., D.A. Brow, H. Roiha, and C. Guthrie. 1987. An essential snRNA from $S$. cerevisiae has properties predicted for U4, including interaction with a U6-like snRNA. Cell 50: $585-592$.

Treco, D.A. 1989. Saccharomyces cerevisiae, Current protocols in molecular biology (eds F.M. Ausubel, R. Brent, R.E. Kingston, D.D. Moore, J.G. Seidman, J.A. Smith, and K. Struhl), pp. 13.12.1-13.12.3. Greene Publishing Associates and Wiley-Interscience, New York.

Tschudi, C., A.R. Krainer, and E. Ullu. 1988. The U6 small nuclear RNA from Trypanosoma brucei. Nucleic Acids Res. 16: 11375.

van der Veen, R., A.C. Arnberg, G. van der Horst, L. Bonen, H.F. Tabak, and L.A. Grivell. 1986. Excised group II introns in yeast mitochondria are lariats and can be formed by selfsplicing in vitro. Cell 44: 225-234.

Vankan, P., C. McGuigan, and I.W. Mattaj. 1990. Domains of U4 and U6 snRNAs required for snRNP assembly and splicing complementation in Xenopus oocytes. EMBO I. 9: 33973404.

Vieira, J. and J. Messing. 1987. Production of single-stranded plasmid DNA. Methods Enzymol. 153: 3-11.

Wang, C., H. Gao, B.L. Gaffney, and R.A. Jones. 1991. Nitrogen15-labeled oligodeoxynucleotides. 3. Protonation of the adenine $\mathrm{N} 1$ in the A-C and A-G mispairs of the duplexes (d[CG $\left({ }^{15} \mathrm{~N}^{1}\right)$ AGAATTCCCG] $)_{2}$ and (d[CGGGAATTC $\left({ }^{15} \mathrm{~N}^{1}\right)$ ACG $)_{2}$. J. Am. Chem. Soc. 113: 5486-5488.

Wassarman, D.A. and J.A. Steitz. 1992. Interactions of small nuclear RNA's with precursor messenger RNA during in vitro splicing. Science 257: 1918-1925.

Wise, J.A., D. Tollervey, D. Maloney, H. Swerdlow, E. Dunn, and C. Guthrie. 1983. Yeast contains small nuclear RNAs encoded by single copy genes. Cell 35: 743-751.

Wolff, T. and A. Bindereif. 1993. Conformational changes of U6 RNA during the spliceosome cycle: An intramolecular helix is essential both for initiating the U4-U6 interaction and for the first step of splicing. Genes \& Dev. 7: 1377-1389.

$\mathrm{Wu}, \mathrm{J}$. and J.L. Manley. 1991. Base pairing between U2 and U6 snRNAs is necessary for splicing of a mammalian premRNA. Nature 352: 818-821.

Yean, S.-L. and R.-J. Lin. 1991. U4 small nuclear RNA dissociates from a yeast spliceosome and does not participate in the subsequent splicing reaction. Mol. Cell. Biol. 8: 814-821.

Zavanelli, M.I. and M. Ares, Jr. 1991. Efficient association of U2 snRNPs with pre-mRNA requires an essential U2 RNA structural element. Genes \& Dev. 5: 2521-2532.
Zavanelli, M.I., J.S. Britton, A.H. Igel, and M. Ares, Jr. 1994. Mutations in an essential U2 snRNA structure cause cold sensitive U2 snRNP function by favoring competing alternative U2 RNA structures. Mol. Cell. Biol. (in press). 


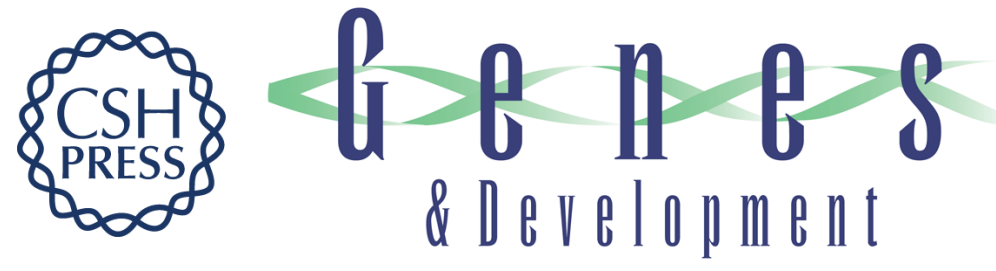

\section{A stem/loop in U6 RNA defines a conformational switch required for pre-mRNA splicing.}

D M Fortner, R G Troy and D A Brow

Genes Dev. 1994, 8:

Access the most recent version at doi:10.1101/gad.8.2.221

References This article cites 59 articles, 23 of which can be accessed free at:

http://genesdev.cshlp.org/content/8/2/221.full.html\#ref-list-1

License

Email Alerting

Service

Receive free email alerts when new articles cite this article - sign up in the box at the top right corner of the article or click here.

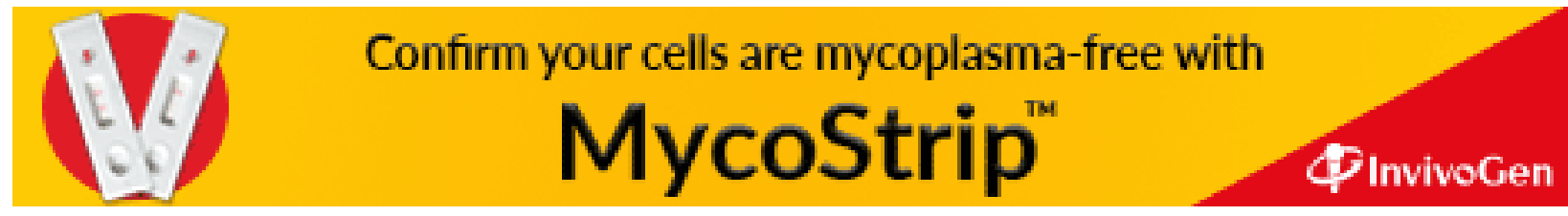

